\title{
The Importance of Higher Education Websites and its Usability
}

\author{
Mirfa Manzoor ${ }^{1}$, Walayat Hussain ${ }^{2}$, Aftab Ahmed ${ }^{3}$, Mohammad Javid Iqbal ${ }^{4}$ \\ ${ }^{1}$ Lecturer, Department of Computer Science, Sardar Bahadur Women's \\ University, Quetta. \\ Email: Mirfa.khan@yahoo.com \\ ${ }^{2}$ Assistant Professor, Department of Computer Science, Balochistan University of \\ Information \& Technology, Quetta. \\ Email: walayathussain@yahoo.com \\ ${ }^{3}$ Associate Professor, Department of Computer Science, BUITEMS, Quetta. \\ Email: Aftab.ahmed@buitms.edu.pk \\ ${ }^{4}$ Assistant Professor, Department of Computer Science, Sardar Bahadur Women's \\ University, Balochistan. \\ Email: javidkm@yahoo.com
}

\begin{abstract}
Now a days the need for higher education institutions to a have a reliable, effective and attractive web presence is increasing as online technology is becoming an important part of the educational process. The higher education institutions play a vital role in the development of a society while higher education websites have many roles to fill. They need to provide information for prospective students, current students, Faculty and alumni. They often need to include reams of information in a way that makes everything easy to explore and it's a great challenge. The purpose of this research is to highlight some points, which will show the importance of higher education websites where we have studied lots of literature to be more focused on the topic and conducted a survey to evaluate the usability of two websites. The paper will be helpful for the higher authorities and the web developers to analyze the significance of the website of higher education institutes and its usability.
\end{abstract}

Keywords: Higher education, Higher education website, Usability of higher education websites. 


\section{Introduction}

\subsection{Higher Education}

Many people are confused about the Higher Education, because there have been many changes recently, including institutions changing their names and titles and degree programs. The Higher education can be defined as a university level education. It offers a number of qualifications ranging from Higher National Diplomas and Foundation Degrees to Honors Degrees and as a further step, Postgraduate programs such as Masters Degrees and Doctorates. These are recognized throughout the world as representing specialist expertise supported by a wide range of skills that is very useful. [1]

\subsection{The Goals of Higher Education}

Hayward Keniston defines the goal of higher education in his research and said that "the goals of higher education are identical with those of all education: the development of an informed, responsible citizenry and the preparation of every boy and girl for a personally satisfying and socially useful career. If we have achieved these goals, if we have capitalized to the maximum the intellectual resources of our youth, it is time for us to take a fresh look at our present educational structure and philosophy" [2].

There is another theory given by Steven Schwartz is "The goal of university education is to help build a fairer, more just society" [3].

The goal of Higher education was clearly defined in 1997 by the National Committee of Inquiry into Higher Education, chaired by the Ron and later, Lord, and Dearing. Widely accepted, the definition is as follows: [4]

- To inspire and enable individuals to develop their capabilities to the highest potential levels throughout life, so that they grow intellectually, are well equipped for work, can contribute effectively to society and achieve personal fulfillment

- To increase knowledge and understanding for their own sake and to foster their application to the benefit of the economy and society

- To serve the needs of an adaptable, sustainable, knowledge-based economy at local, regional and national levels

- To play a major role in shaping a democratic, civilized, inclusive society 


\subsection{The Need of Higher Education Website}

"Higher education is about taking your education to the next level: learning new things and getting to where you want to be."

In our research, we have emphasized on the importance of websites of the universities. The following points clearly demonstrate the need and importance of a website for higher education institutes. [19],[20],[21]

1. Today, it is completely unimaginable that a university would exist without a website. Bad, good, awesome, terrible - it does not matter, you have one. It is expected, demanded, and if you did not, it would have a devastating impact on the impression people have.

2. The higher education institute has a need for an effective website to help with attracting new students as well as for serving the needs of current students.

3. Higher education institutes needs to make a website to globally in print the opportunities provided by their institute so it can be accessed world widely

4. Higher education institutions and programs can elect to go through a peer reviews process that is coordinated by private and state accredits organizations. These organizations are made up of higher education professionals who evaluate quality based on the organization's established standards.

5. Higher education web sites provide all the information about the courses that could boost a student's career prospects and earning potential, while giving them the chance to immerse themselves in a subject that really of their interests.

6. One of the goals that can be achieved by authorizing a HE (higher education) website is to ensure that education provided by institutions of specific higher education meets acceptable levels of quality.

7. Since the government itself does not supervise all post-secondary education, the authorization system development to ensure that higher education institutions are providing a "basic level of quality".

8. The private and state accredit organizations itself do not oversee each higher education institutions individually, due to this reason a website is evolved to ensure that higher education institutions are providing a "basic level of quality" and each institute can be easily accessed by private and 
state accredit organizations and quality education provided by the specific institute can inspect easily.

9. It is a best to make a website of an HE institute so selection of the correct institute can be easier and more efficient for the students. As Higher education is a very different experience to school or further education.

10. Higher education's institutes need a web site to globally compete with the other Higher education's institutes.

11. The university needs to promote institute activities online as well as provide information on its achievement and other programs, which can be achieved through the university website because it gives an identity to the institute worldwide and can be accessible to anyone from anywhere.

12. Now a day the online registration is a very useful feature of the website, which needs to be added in the website to facilitate their students.

13. It also provides the detailed course catalog to their students.

14. It also helps to maintain the record of faculty by having a detailed academic profile of each faculty.

\section{Literature Review}

\subsection{The Goals Higher Education Website}

The higher education websites need a great attention in terms of its development. The website must appeal to the university's commercial interests, which are primarily the sources of presenting their objectives to the visitors and especially to those visitors who are interested in seeking information. It also aims to facilitate their prospective students and scholars by providing the proper guidelines on the website to help them accordingly. Nevertheless, of equal importance, a university website should serve the non-commercial information that is the need of its current students and faculty. Information like the complexities of curriculum choices and the information about the daily events and procedures that happens within a busy university campus. Therefore, usability is considered the key credentials of effective higher education website design. [5] 


\subsection{Usability of Higher Education Website}

The World Wide Web connects people via the internet and makes millions of web resources accessible for them. The website is the collection of related documents. The website usability and design has attracted much attention in the fields of human computer interaction and web specific usability research. Today's the access of the internet is common so the popularity of the websites has been increased. The millions of new web pages are designed daily; many of these are designed and developed by the people who give little attention to the fact that how this information will be used and who will use. It would be very beneficial to provide guidelines and frameworks for making the pleasing user experiences in such systems.

The usability of the higher education website has got great popularity because of its importance. In order to achieve their goals the higher education institution must consider the usability factor when developing their website.

A key short-term goal of net design education should be to understand how to communicate interactively, to focus on the user. [6]

Following there are some usability theories, said by the usability expert Jakob Neilsen. [6]

- He stated in his research about the successful development of the internet as a source of communication, could only be happening when education unpicks the bad design strategies learned over the past years. There is need to follow the latest development strategies of considering usability in a system.

- In New York Times, he said about the failure of web design and emphasis on the key features of usability theory and its implementation in undergraduate design courses.

- In his London conference, he focused on the organization's strategies towards hiring and firing the web designers where they see the glamorous design that simply is not the need. Therefore, there is a wasteful process of firing and hiring designers.

- Nielsen stressed on the need of more usability expert design students in the methods of simplicity who will be able to tell the institutions change your web strategies or you will fail.

- Nielsen has also presented the responsibilities of a web designer and said "Web designers have a responsibility not just to do what they are told, but also to tell firms when they are forcing through decisions that waste money." 
- In the new economy, the user interface is the company, he says. "The company is the screen. Therefore, design will be tested. User tracking surveys show the miserable nature of the web now. Users do not click through. The drop-off rate is appalling.

- "The old economy's ways will not work anymore. The marketing techniques that identified consumers as masses of varying sizes, with the aim of learning how to manipulate them, will no longer apply to the networked economy."

- Neilsen, in his book "Designing Web Usability", said: "These goals are forgotten about in most design degree courses. The art school aesthetic behold the beauty - does not apply either.

- "Usability redefines the culture of design and commerce. The networked economy demands a pleasant and businesslike experience. Here, look and feels are dominant with the emphasis on feeling, the emotional response."

The usability of the website discusses the following major features, which are essential part of the website.

\subsection{Web Design Structure}

Here we have defined the usability guidelines for a website, which will help to create a better website design. The 16 important research findings about the web design is necessary to be discussed here which are given below.

1. Design is a key determinant to building online trust with consumers. For motivated users of an information site, bad design (busy layout, small print, too much text) hurts more than good design helps [7].

2. Layout of a web page (whitespace and advanced layout of headers, indentation, and figures) may not measurably influence performance, but it does influence satisfaction [8].

3. Experience matters: Blue links are easier to click than black ones, even though black ones have higher visual contrast and are easier to see [9].

4. The acceptance and impact of animation is enhanced when users are warned to expect it and allowed to start it when they want [10].

5. Users will wait longer for better content. Users will wait between 8-10 seconds for information on the Web, depending on the quality of the information [11]. 
6. Experienced users will not wait as long as novices [11].

7. Web pages generally vary in three dimensions: layout, navigation support, and information density [12].

8. Over time, Web sites have evolved from big button designs to frames to scattered buttons pages to high color to functionally sub-divided layouts or portal pages [12].

9. In 2001, Bernard found that prior user experience with websites dictated where they expected common web page elements to appear on a page. The same still holds true today: Users have clear expectations about where to find the things they want (search and back-to-home links) as well as the things they want to avoid (advertising) [13].

10. Well written sites significantly reduce confusion, comprehension errors and reading times [14].

11. This effect of bad Web writing will likely be amplified for non-native English speakers [14].

12. Other research on menu and website navigation suggests that users perform best with a large number of choices on introductory screens (i.e., top levels), and fewer choices at deeper levels of a hierarchy. Thus, it will be critical to manipulate text topology in future studies of hypertext reading [15].

13. When assessing web accessibility under four conditions (expert review, screen reader using JAWS, automated testing via "Bobby", and remote testing by blind users) those using screen readers find the most issues, while automated testing finds the least number of accessibility issues [16].

14. On sites with clear labels and prominent navigation options, users tend to browse rather than search. Searching is no faster than browsing in this context [17].

15. Use of white space between paragraphs and in the left and right margins increases comprehension by almost $20 \%$ [18].

16. Broken links, performance and "Alt" attribute for images need great attention in order improve the usability of the higher education websites [22]. 


\section{Methodology}

In order to investigate the usability of a higher education website we have selected two university websites, the first is www.sbkwu.edu.pk and the second is www.buitms.edu.pk and tested the usability of the these website using the "Questionnaire" approach. A survey is conducted where the 10 students from each university randomly participated in it. The questionnaire used in the survey consists of 10 questions; the students will answer those questions after visiting their university website thoroughly.

There are following questions used for the evaluation of the websites and the students will simply answer in "No" or "Yes".

1. Do you access your university website?

2. Does it provide you latest news and events updates?

3. Does it provide you the information about the new admissions offered by the university?

4. Does it provide you the feature to access your result online?

5. Does it provide you the facility for online admissions?

6. Does it provide you the updated course detail offered in each program?

7. Does it provide you the Academic profile of each faculty enrolled in university?

8. Does it provide you the information about the fee structure of each program offered in the university?

9. Does it provide you the information about the university policies?

10. Does it provide you the facility to print your result?

\section{Results}

The results taken from the students of BUITEMS are as follows in table 1 . The result is given in percentage for each question. 
Table 1. Usability result of Buitems website

\begin{tabular}{|c|c|c|c|c|}
\hline \multirow[t]{2}{*}{ No. } & \multirow[t]{2}{*}{ Questions } & \multicolumn{3}{|c|}{ Result } \\
\hline & & $\begin{array}{l}\text { Yes } \\
\text { (in percentage) }\end{array}$ & $\begin{array}{l}\text { No } \\
\text { (in percentage) }\end{array}$ & $\begin{array}{l}\text { Don't Know } \\
\text { (in percentage) }\end{array}$ \\
\hline 1. & $\begin{array}{l}\text { Do you visit your university } \\
\text { website? }\end{array}$ & $100 \%$ & 0 & 0 \\
\hline 2. & $\begin{array}{l}\text { Does it provide you latest news } \\
\text { and events updates? }\end{array}$ & $70 \%$ & $20 \%$ & $10 \%$ \\
\hline 3. & $\begin{array}{l}\text { Does it provide you the } \\
\text { information about the new } \\
\text { admissions offered by the } \\
\text { university? }\end{array}$ & $100 \%$ & 0 & 0 \\
\hline 4. & $\begin{array}{l}\text { Does it provide you the feature } \\
\text { to access your result online? }\end{array}$ & $100 \%$ & 0 & 0 \\
\hline 5. & $\begin{array}{l}\text { Does it provide you the facility } \\
\text { for online admissions? }\end{array}$ & 0 & $100 \%$ & 0 \\
\hline 6. & $\begin{array}{l}\text { Does it provide you the updated } \\
\text { course detail offered in each } \\
\text { program? }\end{array}$ & $30 \%$ & $50 \%$ & $20 \%$ \\
\hline 7. & $\begin{array}{l}\text { Does it provide you the } \\
\text { Academic profile of each faculty } \\
\text { enrolled in university? }\end{array}$ & $40 \%$ & $30 \%$ & $30 \%$ \\
\hline 8. & $\begin{array}{l}\text { Does it provide you the } \\
\text { information about the fee } \\
\text { structure of each program } \\
\text { offered in the university? }\end{array}$ & $60 \%$ & $30 \%$ & $10 \%$ \\
\hline 9. & $\begin{array}{l}\text { Does it provide you the } \\
\text { information about the university } \\
\text { policies? }\end{array}$ & $90 \%$ & 0 & $10 \%$ \\
\hline 10. & $\begin{array}{l}\text { Does it provide you the facility } \\
\text { to print your result? }\end{array}$ & $100 \%$ & 0 & 0 \\
\hline
\end{tabular}


The following there is survey result collected from the SBK University shown in table 2.

Table 2. Usability result of SBK website

\begin{tabular}{|c|c|c|c|c|}
\hline No. & Questions & \multicolumn{3}{|c|}{ Result } \\
\hline & & $\begin{array}{l}\text { Yes } \\
\text { (in percentage) }\end{array}$ & $\begin{array}{l}\text { No } \\
\text { (in percentage) }\end{array}$ & $\begin{array}{l}\text { Don't Know } \\
\text { (in percentage) }\end{array}$ \\
\hline 1. & $\begin{array}{l}\text { Do you visit your university } \\
\text { website? }\end{array}$ & $100 \%$ & 0 & 0 \\
\hline 2. & $\begin{array}{l}\text { Does it provide you latest news } \\
\text { and events updates? }\end{array}$ & $50 \%$ & $40 \%$ & $10 \%$ \\
\hline 3. & $\begin{array}{l}\text { Does it provide you the } \\
\text { information about the new } \\
\text { admissions offered by the } \\
\text { university? }\end{array}$ & $80 \%$ & $20 \%$ & 0 \\
\hline 4. & $\begin{array}{l}\text { Does it provide you the feature } \\
\text { to access your result online? }\end{array}$ & $20 \%$ & $80 \%$ & 0 \\
\hline 5. & $\begin{array}{l}\text { Does it provide you the facility } \\
\text { for online admissions? }\end{array}$ & 0 & $100 \%$ & 0 \\
\hline 6. & $\begin{array}{l}\text { Does it provide you the updated } \\
\text { course detail offered in each } \\
\text { program? }\end{array}$ & $30 \%$ & $60 \%$ & $10 \%$ \\
\hline 7. & $\begin{array}{l}\text { Does it provide you the updated } \\
\text { academic profile of each faculty } \\
\text { enrolled in university? }\end{array}$ & $20 \%$ & $70 \%$ & $10 \%$ \\
\hline 8. & $\begin{array}{l}\text { Does it provide you the } \\
\text { information about the fee } \\
\text { structure of each program? }\end{array}$ & $90 \%$ & $10 \%$ & $0 \%$ \\
\hline 9. & $\begin{array}{l}\text { Does it provide you the } \\
\text { information about the university } \\
\text { policies? }\end{array}$ & $10 \%$ & $70 \%$ & $20 \%$ \\
\hline
\end{tabular}




\begin{tabular}{|l|l|l|l|l|}
\hline 10. & $\begin{array}{l}\text { Does it provide you the facility } \\
\text { to print your result? }\end{array}$ & $10 \%$ & $80 \%$ & $10 \%$ \\
\hline
\end{tabular}

Here is a graphical representation of the usability survey result of Buitems website. The fig 1 clearly demonstrates the usability level of the website and area which needs improvements.

Figure 1. Usability result of Buitems website.

\section{Usability result of Buitems website}

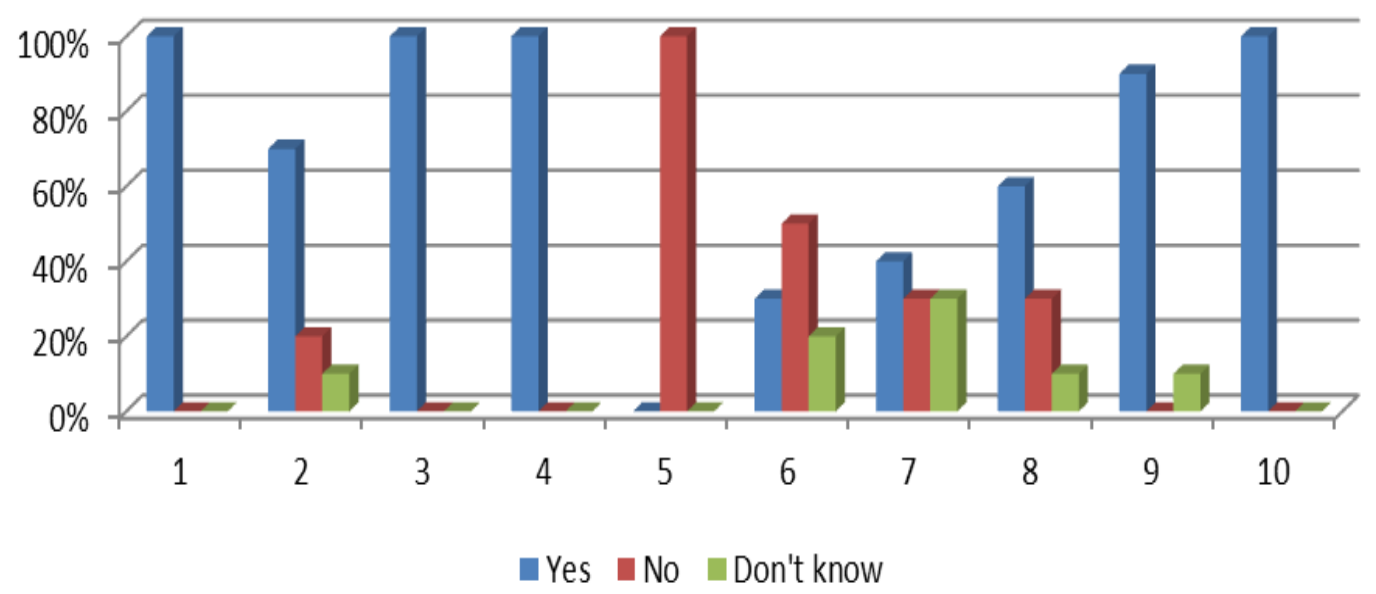

The usability survey result of SBK University in fig 2 clearly demonstrates the usability level of the website and area, which needs improvements. 
Figure 2. Usability result of SBK website.

\section{Usability result of SBK university}

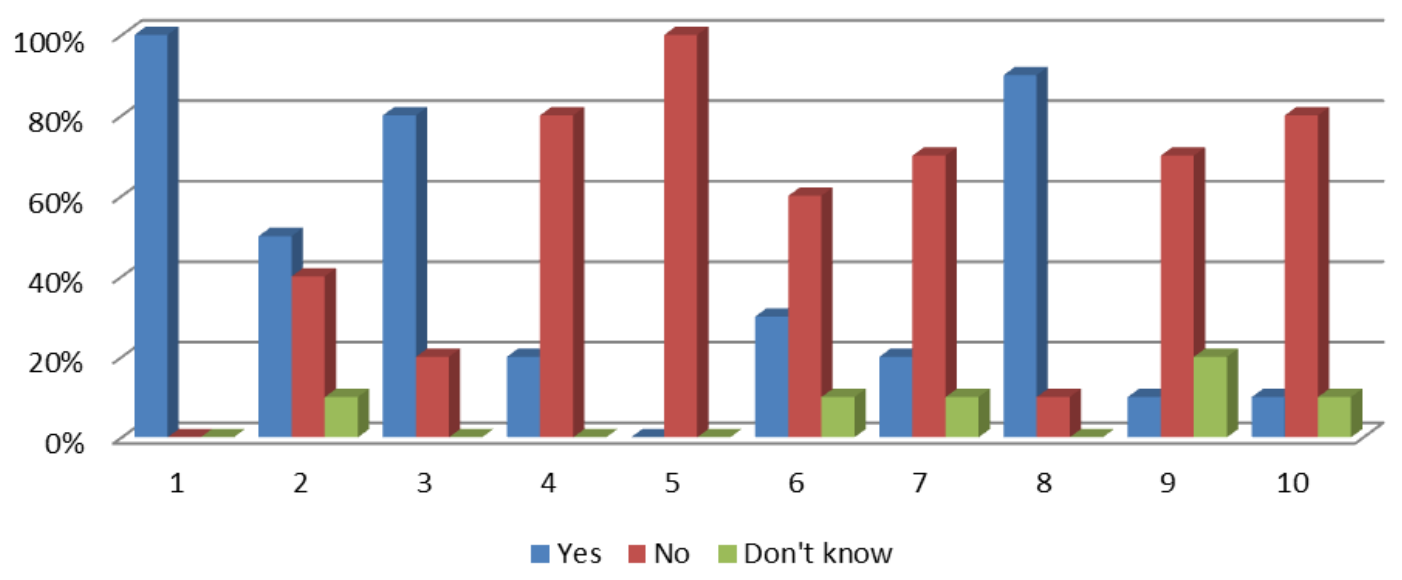

\section{Conclusion}

The results revealed that the both the universities were not $100 \%$ usable for their students. We observed that some of the students were unable to access some of the features defined in the questionnaire so they could not answer in "yes" or "No" which also affects the result but the website should be easy to explore so that the students can get their desired data. Secondly, when we compare the usability level of these both websites, the Buitems university website has the high usability level as compared to the SBK university website. It provides the online result facility, updated faculty profile, latest news and event updates etc. The web developers need to focus on the area, which needs still improvements because both of the websites are partially usable.

\section{ACKNOWLEDGEMENT}

First, I am grateful to Almighty Allah, whose blessings have always given me the strength to complete this task. It is a great honor and privilege for me to record this deep sense of gratitude to my honorable supervisors Mr. Walayat Hussain their continued guidance and encouragement during the work. My special thanks are for my family especially my mother whose prayers, love and care are the continuous source of encouragement for me. 


\section{References}

[1] What is Higher Education? http://www.wg.aegee.org/ewg/higheredu.htm [accessed 2012-3- 05]

[2] The Goals of Higher Education, Hayward Keniston Proceedings of the American Philosophical Society, Vol. 104, No. 6 (Dec. 15, 1960), pp. 565569

[3] The higher purpose: http://www.timeshighereducation.co.uk/story.asp?storycode $=176727$ [accessed 2012-3- 05]

[4] DEARING, R. Report of the National Committee of Inquiry into Higher Education. Chapter 5, paras. 5.10 11. [online] 1997. Available at: https://bei.leeds.ac.uk/Partners/NCIHE [Accessed 2012- 04-05]

[5] Oneupweb : How Higher Education Handles Website Design-No Student Loan Required http://www.straightupsearch.com/design-usability/oneupwebhow-higher-education-handles-website-designno-student-loan-required/

[6] Tim Greenhalgh, 17 March 2000 "The Guru of usability speaks" http://www.timeshighereducation.co.uk/story.asp?storyCode $=150704 \&$ sectio ncode $=26$ [Accessed 2012-06-05]

[7] Sillence, E., Briggs, P., Fishwick, L. \& Harris, P. (2004). Trust and Mistrust of Online Health Sites. Proceedings of CHI'2004, April 24-29 2004, Vienna Austria, p663-670. ACM press

[8] Chaparro, B. S., Shaikh, A. D., and Baker, J. R. (2005). "Reading Online Text with a Poor Layout: Is Performance Worse?" Usability News, 7(1).

[9] Van Schaik, P., \& Ling, J., The effect of link colour on information retrieval in educational intranet use (2003). Computers in Human Behavior 19, 553564.

[10] Weiss, R., Knowlton, D., \& Morrison, G.R., Principles for using animation in computer-based instruction: Theoretical heuristics for effective design (2002). Computers in Human Behavior 18, 465-477

[11] Ryan, G. \& Valverde, M., Waiting online: A review and research agenda (2003). Internet Research: Electronic Networking Applications and Policy 13 (3), 195-205.

[12] Ryan, T., Field, R.H.G., Olfman, L., The evolution of US state government home pages from 1997 to 2002 (2004). International Journal of HumanComputer Studies, in press.

[13] Shaikh, A., and K. Lenz. 2006. Where's the Search? Re-Examining User Expectations of Web Objects. psychology.wichita.edu/surl/usabilitynews/81/webobjects.asp.

[14] Ozok, A.A., \& Salvendy, G., The effect of language inconsistency on performance and satisfaction in using the Web: Results from three experiments (2003). Behavior \& Information Technology 22 (3), 155-163. 
[15] Parush, A., \& Yuviler-Gavish, N. (2004). Web navigation structures in cellular phones: The depth/breadth tradeoff issue. International Journal of Human-Computer Studies, 60(5-6), 753-770.

[16] Jennifer Mankoff, Holly Fait, and Tu Tran, "Is your web page accessible? A comparative study of methods for assessing web page accessibility for the blind," In Proceedings of CHI 2005pp. 41-50. (ACM DOI, pdf)

[17] Katz, M. A., \& Byrne, M. D. (2003). Effects of scent and breadth on use of site-specific search on e-commerce Web sites. ACM Transactions on Computer-Human Interaction, 10, 198-220. [PDF]

[18] Lin, D. M. (2004). Evaluating older adults_ retention in hypertext perusal: Impacts of presentation media as a function of text topology. Computers in Human Behavior, 20(4), 491-503.

[19] Education Guru: http://doteduguru.com [Accessed 2012- 04 -05]

[20] Direct Government: http://www.direct.gov.uk [Accessed 2012- 12-05]

[21] Online College: http://www.onlinecollege.org/ [Accessed 2012- 12-05]

[22] Manzoor, M., \& Hussain, W. (2010). Usability Evaluation of Higher Education Websites. Science Series Data Report, Vol 4, No. 3;Mar 2012 